\title{
EHMTI-0130. Questioning the presence of iron deficiency anemia in migrane and tension type headache: a case control study
}

\author{
S Gur Ozmen ${ }^{1 *}$, R Karahan Ozcan ${ }^{2}$ \\ From 4th European Headache and Migraine Trust International Congress: EHMTIC 2014 \\ Copenhagen, Denmark. 18-21 September 2014
}

\section{Background}

Generally speaking headache is an accepted symptom of iron deficiency anemia (IDA). However, it is not very clear which type of headache has an association with IDA, either migrane or tension type headache.

\section{Aim}

To evaluate the presence of iron deficiency anemia (IDA) in migraine and TTH patients, as well as in controls.

\section{Method}

A case-control clinical study was conducted to investigate the presence of IDA in 169 migraine, 165 TTH patients and in 170 healthy controls. Migraine and TTH diagnosis was settled according to the International Classification of Headache Disorders-II diagnostic criteria, and each subject was evaluated in terms of headache characteristics including severity, frequency, duration of the headache attack, and the duration of the disease. Routine hematological analysis was applied for all of the groups. Descriptive statistics and multivariate regression analysis were performed.

\section{Results}

IDA was observed in $21 \%$ of the patients with migraine and in $15 \%$ with TTH whereas it was observed in $12 \%$ of the healthy controls. IDA was found to be significantly higher in patients with migraine than controls $(P=0.03)$. IDA was independently associated with migraine in multivariate model (OR: 1.88; CI 95\% 1.01-3.50, $\mathrm{P}=0.04$ ). Age $(\mathrm{P}=0.02)$ and duration of menstrual bleeding $(\mathrm{P}=0.006)$ were the factors affecting presence of IDA in migraine. There was no association between TTH and IDA.

${ }^{1}$ Neurology, Igdir State Hospital, Igdir, Turkey

Full list of author information is available at the end of the article

\section{Conclusion}

Our results suggest that IDA is prevalent in migraine patients but not in TTH. This finding should be validated in further patient series.

No conflict of interest.

\section{Authors' details}

${ }^{1}$ Neurology, Igdir State Hospital, Igdir, Turkey. ${ }^{2}$ Neurology, Gebze Fatih State Hospital, Kocaeli, Turkey.

Published: 18 September 2014

doi:10.1186/1129-2377-15-S1-D25

Cite this article as: Ozmen and Ozcan: EHMTI-0130. Questioning the presence of iron deficiency anemia in migrane and tension type headache: a case control study. The Journal of Headache and Pain 2014 15(Suppl 1):D25.

\section{SpringerOpen ${ }^{\odot}$}

(c) 2014 Ozmen and Ozcan; licensee Springer. This is an Open Access article distributed under the terms of the Creative Commons Attribution License (http://creativecommons.org/licenses/by/2.0), which permits unrestricted use, distribution, and reproduction in any medium, provided the original work is properly cited.
Submit your manuscript to a SpringerOpen ${ }^{\circ}$ journal and benefit from:

- Convenient online submission

- Rigorous peer review

- Immediate publication on acceptance

- Open access: articles freely available online

- High visibility within the field

- Retaining the copyright to your article

Submit your next manuscript at $>$ springeropen.com 